Wayne Kondro. ${ }^{1}$ There is indeed fragmentation in the organization of the organ and tissue donation and transplantation system in Canada, and Canadian donation rates are a concern.

We know that the Canadian organ and tissue donation and transplantation system is complex and the optimal made-in-Canada solution to improving patient outcomes and quality of life needs to be found through collaboration, consensus and coordination. As a national nonprofit organization with a mandate to provide advice to the Conference of Deputy Ministers of Health on improving the organ and tissue donation and transplantation system, the CCDT is a catalyst for change in this system.

Measures such as donation rates can be informative. We have learned, though, that international donation rates are not measured in the same way. Thus, comparing Canadian donation rates to those in other countries may not be a useful way to mark Canadian progress.

Kondro cites the United Network for Organ Sharing in the United States as a model to solve the current problems in the Canadian system. There are some things that we can learn from this model, but it may be significantly less applicable in our country because of the different health care context in Canada. The United Network for Organ Sharing is a regulatory body that specializes in organ allocation, but, according to our stakeholders, efficiency in allocation is not the only issue that needs to be addressed to improve patient outcomes.

The CCDT, physicians and other health care providers involved in donation and transplantation seek to ensure that people requiring transplantation have access to the care they need at the earliest opportunity. The creation of a made-in-Canada system is already evolving through national dialogue and deliberation about best practices in donation and transplantation. ${ }^{2-4}$ We look forward to further consensus recommendations from experts in the field and trust that regional authorities will implement them, as they have done in the past.

Canada has centres of excellence with high donation rates, and the role of the CCDT is to support the transfer of this excellence throughout our country. All stakeholders in the organ and tissue donation and transplantation system want to move more quickly because lives are being lost.

\section{David Hollomby}

Chair

CCDT Transplantation Committee

London, Ont.

Marc Germain

Chair

CCDT Tissue Committee

Québec, Que.

Sam Shemie

Chair

CCDT Donation Committee

Montréal, Que.

\section{Leah Hollins}

Chair

CCDT Council

Victoria, BC

Kimberly Young

Chief Executive Officer

CCDT

Edmonton, Alta.

\section{REFERENCES}

I. Kondro W. Fragmented organ donation programs hinder progress. $C M A J$ 2006;175(9):1043

2. Shemie SD, Doig C, Dickens B, et al. Brain arrest: the neurological determination of death and organ donor management in Canada: Severe brain injury to neurological determination of death: Canadian forum recommendations. CMAJ 2006;174(6 Suppl):SI-SI2.

3. Shemie SD, Ross H, Pagliarello J, et al. Brain arrest: the neurological determination of death and organ donor management in Canada: Organ donor management in Canada: recommendations of the forum on Medical Management to Optimize Donor Organ Potential. CMAJ 2006;174(6 Suppl):SI3-S30.

4. Shemie SD, Baker AJ, Knoll G, et al. National recommendations for donation after cardiocirculatory death in Canada. CMAJ 2006;175(8 Suppl):SI-S24.

DOI:I0.I503/cmaj.I060220

Wayne Kondro's recent article on organ donation programs ${ }^{1}$ highlights some of the challenges that the Canadian transplant community faces as it responds to the changes that have occurred in the transplantation landscape over the last 3 or 4 decades. Although a national organ donation agency may be beneficial, it is inaccurate to suggest, as Kondro does, that a nationwide waitlist does not exist and that organ sharing is somehow an afterthought.

For more than 20 years, the liver transplant community has had a nationwide agreement on wait-list priority for both urgent and nonurgent cases. This allocation system includes a consensus on organ sharing for urgent cases right across the country. A list is updated weekly by each regional organ procurement agency and is disseminated to the transplant centres. About half of the 50-60 urgent liver transplantations each year are performed using organs that come from another region. Although it is informal and operates with limited funding, the "liver study group" meets annually, has achieved consensus on many difficult issues and continues to find ways to optimize liver allocation and transplantation outcomes across Canada.

The driving forces behind changes in organ allocation policy in the United States are not exactly the same as those in Canada; solutions should be sought that reflect our reality. Where a national agency may be most beneficial is in providing the infrastructure to gather the statistics that will be most useful in tracking trends in transplantation. This will permit stakeholders to implement the necessary modifications in practice in a timely manner.

\section{Steven R. Martin}

Liver Transplant Service

Hôpital Sainte-Justine

Université de Montréal

Montréal, Que.

\section{REFERENCE}

I. Kondro W. Fragmented organ donation programs hinder progress. CMAJ 2006;175(9):1043.

DOI:I0.1503/cmaj.Io602I9

Wayne Kondro has pointed out the weaknesses in our organ donation programs in Canada. ${ }^{1}$ In the United States, the Department of Health and Human Services vigorously took up the challenge of increasing organ donation rates. It established the Organ Donation Breakthrough Collaborative to increase the likelihood that initiatives to improve organ donation rates will be successful. The Centers for Medicare and Medicaid Services established conditions of participation designed to enhance organ donation in all hospitals 